\title{
On Yijing in Chinese and English Nature Poetry: The Case Study of Wordsworth and WANG Wei
}

\author{
BAI Li-bing \\ Central University of Finance and Economics, Beijing, China
}

\begin{abstract}
The nature poetry written by English Romantic poet William Wordsworth (1770 AD-1850 AD) is a milestone in English literary history. Its inbuilt aesthetics transcended English poetics and reached the realm of Yijing, which is regarded as the highest achievement in Chinese poetics for nature poetry. In this perspective, poems written by TANG Dynasty poet WANG Wei (王维) can be well compared. Though they share similarities in aesthetical perception, the differences cannot be neglected: One difference is the contrast of emptiness and substantiality; the other lies in clarity and vagueness. This mutual illumination will not only build a channel in comparative literature and enhance cultural communication, more importantly, it also discovers the potential values of the two: First, Wordsworth's unique aesthetical awareness is forwarded. Second, it helps to promote the value of ancient Chinese poetic theory.
\end{abstract}

Keywords: Yijing, nature poetry, Wordsworth, WANG Wei, comparison

\section{Introduction}

Chinese Mountain-Water Poetry (山水诗) or nature poetry has a long tradition. But the correspondent poetic genre in English literature started very late. Poetry before English Romanticism seldom depicted natural scenes. English Romantic poet William Wordsworth (1770 AD-1850 AD) had a sharp perception on nature and wrote several beautiful nature poems. These nature poems are also among the best in English poetry, such as "Tintern Abbey” (1798), “Daffodils” (1804), and “Westminster Bridge” (1802), etc.. Wordsworth’s nature poetry is not only a milestone in English history of poetry, but also a masterpiece according to ancient Chinese aesthetics of nature poetry, for which Yijing (意境, or the associated mind realm in natural objects) is considered the highest achievement. This paper mainly focuses on the poetic Yijing in Wordsworth's poem "Daffodils" (or "I Wandered Lonely as a Cloud”, 1804), and brings Chinese nature poetry written by early TANG Dynasty poet WANG Wei (王维, about 660 AD-720 AD) into comparison.

This paper utilizes the methodology of literary hermeneutics to evaluate Wordsworth's nature poetry from a perspective of Chinese poetical aesthetics, and compares the similarities and differences of Yijing in English and Chinese nature poetry. The justification for such an intercultural dialogue lies in the universality of aesthetical perception of human mind - that is, a common poetic heart. This approach of mutual-hermeneutics digs a channel for the free interchangeability and mutual illumination of common poetic experiences in different national literatures.

BAI Li-bing, lecturer, Ph.D., School of Foreign Studies, Central University of Finance and Economics. 


\section{Similarities}

In Chinese literary history, skills of writing nature poetry were already superb in high TANG Dynasty (618 AD-907 AD), not only the poetic visions much broadened, but also transferred from realistic portray of natural objects to the exploration of rich implications. The poets tried to entrust sublimity in commonality, to see the deep meaning under surface scenery. Poets at this time had the perfect artistry in gathering and refining imagery and in handling between actualities and virtualities, thus, the image beyond images, or Yijing became the criterion of nature poetry evaluation. Yijing is produced by a series of imagery compounding and sublimating, it is a metaphysical quality generated from the overall atmosphere of poetry. The beauty of Yijing can only be perceived by the reader's aesthetical awareness; it can hardly be described in theories. The TANG Dynasty poet WANG Chang-ling (王昌龄, 698 AD-756 AD) first used the term Yijing in Chinese poetry criticism:

That the poetry has three stages, the first is the stage of natural objects. In writing the nature poetry, one should look at springs, stones, clouds, and mountains, imagine the most beautiful scenes in the heart, move into the scene and observe it by mind, as if it becomes crystal-clear in one's hand, then think about it and get the formal resemblance. The second is the stage of emotion, in which joys and sorrows permeated mentally and physically, then gallop one's wild thoughts, and get the temperament. The third stage is Yijing, also take a mind view and inward thinking, and then get the very essence of Truth. ${ }^{1}$

Yijing by itself is an artistic realm, in which the poet may express his feelings, ideas, and aesthetic perceptions that have transcended the reality. The beauty of Yijing in art is derived from a clear and calm mind. It has a long tradition in Chinese culture, as early as Lao Tzu’s “purified mind and penetrating vision” (涤除玄览

《老子. 十章》, n.d.) or Zhuang Tzu’s “mind-abstinence” (心斋《庄子. 人间世》, n.d.). LU Ji (陆机, 261 AD-303 AD) in West JIN Dynasty wrote in his Wenfu (《文赋》, 300 AD): “Completely forbid hearing and seeing, concentrate the mind; let thought spread to everywhere and travel a vast distance”². ZONG Bing (宗炳, 375 AD-433 AD) of the Southern Dynasties also had a famous saying: "Empty the mind and ponder on the imagery"3. The SONG Dynasty literary master SU Shi (苏轼, 1037 AD-1101 AD) held the similar view: "If one wants the verses to be perfect, just sink into emptiness and calmness; in calmness one can understand other's activity, and in emptiness, one can incorporate it into infinite varieties”4.

English Romantic poets attempted to combine the internal and external, and stressed the power of imagination in artistic creation; this laid a foundation for creating Yijing in nature poetry. Wordsworth (2001) said that poetry originates from "emotion recollected in tranquility" (p. 665). He put forward the syllogism for poetry writing: excitement—calmness—re-excitement. The first excitement is determined by the poet's sensitivity; then keep distance and give an clear afterthought; at last, use the rich imagination to recall the vivid scene, and relive the experience. The thoughts precipitation like that of Wordsworth is a necessary process to achieve Yijing. Sidney (1554 AD-1586 AD) wrote in An Apology for Poetry (2002):

\footnotetext{
1 “诗有三境：一曰物境。欲为山水诗, 则张泉石云峰之境, 极丽绝秀者, 神之于心, 处身于境, 视境于心, 莹然掌 中, 然后用思, 了然境象, 故得形似。二曰情境。娱乐愁怨, 皆张于意而处于身, 然后驰思, 深得其情。三曰意境。亦 张之于意而思之于心 , 则得其真矣” (GUO, 2001, p. 88).

2 “收视反听, 耽思傍讯, 精敬八极, 心游万仞” (LU, 2002, p. 36).

3 “澄怀味象” (Beijing Daxue Zhexuexi, 1981, p. 177).

4 “欲令诗语妙, 无厌空且静。静故了群动, 空故纳万境” (Beijing Daxue Zhexuexi, 1981, p. 35).
} 
Only the poet, disdaining to be tied to any such subjection (to nature), lifted up with the vigor of his own invention, doth grow in effect into another nature, in making things either better than Nature bringeth forth, or, quite anew, forms such as never were in Nature. (p. 85)

Wordsworth tried to transcend the debate between Romantic and Neoclassical poetics, and to reach a higher balance or harmony of artistic interests, a sublime realm. His poem "Daffodils" serves as a good example, even judged by the criterion of Yijing in Chinese poetics:

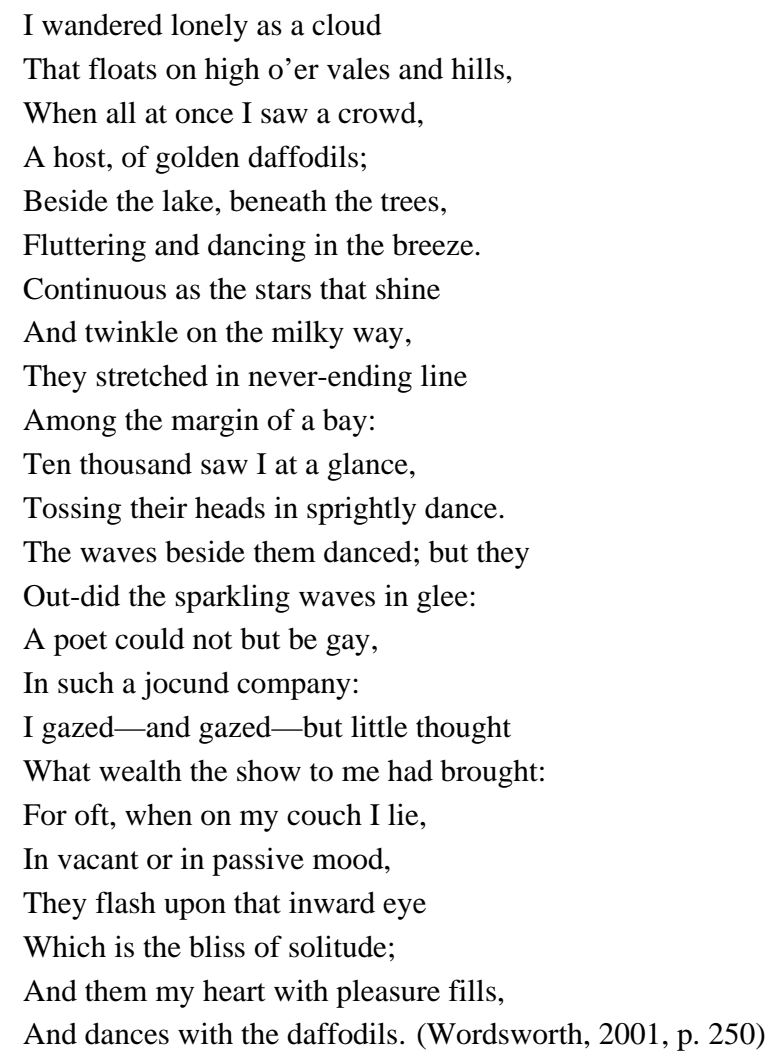

When walking in the wild nature, the poet suddenly saw a vast stretch of daffodils by the lake, the astonishing beauty stunned him. He gazed at the flowers, which swayed their heads in the breeze, as if stars hanging on the night sky. He got an illusion; the daffodils become a lively friend shedding the resplendent luster of life. Somehow, a strong feeling of ecstasy came to him. He was wondering the cause of such a mentality. The nature imagery has become Yijing in the poet's heart, which may recall the sweet memory when he was alone. CAI Xiao-shi had a marvelous description of this:

The indirectness serves to exhaust the meaning and the remoteness serves to deepen the tone. At first reading, it shows the flourishing flowers in spring, the fascination of various colors, the white snow covering the vast land, and the splendid rosy clouds glowing on the sky, this is the first stage. The second reading shows the waves of smoke permeating boundlessly, the frost flying in the fierce wind, the steed galloping down the slope, and the fish jumping out of the water, this is the second stage. The last reading shows the bright and clear moon, the poised and elegant cloud, the highflying wild geese, the rain-like falling leaves, one is wondering the cause of plainness and placidness, calmness and detachedness. Jiang Shunyi commented: 'the first stage is dominated by emotion, the second by Qi, or the vital force, the 
last by the virtue of art. $^{5}$

The daffodil in Wordsworth's poetry is not a fixed image of flowers, but surging with dynamic forces. Poetry devoted to Yijing focuses on one instant, which may not come along with reality. The flowers in "Daffodils" change and move with the poet's imagination, though flowers are still flowers, the poet's excitement and happiness are fully demonstrated. Keats (1795 AD-1821 AD) also wrote such verses in the sonnet "When I Have Fears":

When I behold, upon the night's starred face,

Huge cloudy symbols of a high romance. (5-6) (Keats, 1970, p. 296)

When the night falls, it is impossible for the clouds on the sky to cast clear contour of shadows on the ground, so this contour is not a simple metaphor-it is poetic truth, not truth in nature. It consists of a transformed reality-actually a short period of time, in which aggregated so many intense feelings and ideas that are contradictory to and intermingled with each other. Chinese literary tradition also has pithy accounts for the difference between art and reality. HU Ying-lin (胡应麟, 1979) in MING Dynasty gave a good review on ZHANG Ji’s (张继, 715 AD-779 AD) poem “Casting Anchor by the Maple Bridge” (枫桥夜泊) (750 AD):

People talking about the verse "Reach the boat when bell rings in the midnight" are all deceived by the poet. Poetry puts moving scenes in its language only for the sake of rhyme and meter, and for the suitability of imagery inspiration. The poet did not care for the minor facts. Whether it is midnight or not, the bell rings or not, cannot be attested. ${ }^{6}$

WANG Shi-zheng (王士祯, 1634 AD-1711 AD) said: “Most of the ancient poetry and painting only paied attention to the inspiration and instinct, mechanically engaged in textual research will lose its essence”7. The QING Dynasty painter ZHENG Ban-qiao (郑板桥, 1693 AD-1765 AD) also wrote down his experience:

In a riverside mansion, I went out to see bamboos in the morning of a fine autumn day. The smoke, light, and shadow were all drifting among the branches and leaves. I felt the urge to draw a picture. However, the bamboo in my mind was not that in my eyes. When I prepared ink and brush, sudden revisions were made at the juncture of drawing; the bamboo drawn was not that in my mind. In short, the mind before drawing is a rule; while the inspiration was beyond the rules, it is elusive. ${ }^{8}$

\section{Differences}

However, when studying the Yijing of poetry one should not overlook the essential differences of it between Chinese and English nature poetry. The first is the contrast of emptiness and substantiality. Western culture aims at the existence and objects, so the substance becomes the foremost concern. Keats could hardly

\footnotetext{
5 “ 夫意以曲而善托, 调以查而弥深。始读之则万蓦春深, 百色妖露, 积雪缟地, 余霞绮天, 一境也。再读之则烟涛硕 洞, 霜䒝飞摇, 骏马下坡, 泳鳞出水, 又一境也。卒读之而賋晈明月, 仙仙白云, 鸡雁高翔, 坠叶如雨, 不知其何以冲 然而澹，倚然而远去。江顺贻评之曰：始境，情胜也。又境，气胜也。终境，格胜也” (as cited in ZONG, 2005, p. 92). 6 “夜半钟声到客船”, 谈者纷纷, 皆为昔人愚弄。诗借流景立言, 惟在声律之调, 兴象之合, 区区事实, 彼岂暇计? 无论夜半是非，即钟声闻否，未可知也” (HU, 1979, p. 195).

7 “大抵古人诗画, 只取兴会神到，若刻舟缘木求之，失其指矣” (GUO, 2001, p. 370).

8 “ 江馆清秋, 晨起看竹, 烟光日影露气, 皆浮动于疏枝密叶之间。胸中勃勃, 遂有画意。其实胸中之竹, 并不是眼中 之竹也。因而磨墨展纸, 落笔修作变相, 手中之竹, 又不是胸中之竹也。总之意在笔先者, 定则也 ; 趣在法外者, 化机 也。独画云乎哉! ” (Beijing Daxue Zhexuexi, 1981, p. 340).
} 
find a soul mate who really understood the significance of emptiness in his verse "Heard melodies are sweet, but those unheard/Are sweeter” (Keats, 1970, p. 534). The Western philosophy aspired to clarify the entire unknown world, always puts the emptiness as substance. Chinese philosophy regards the emptiness as the destination of universe, “all things come from Being, and Being comes from Nothing” (万物皆生于有，有生 于无《老子. 四十章》, n.d.). Chinese people see the empty space in universe is full of Qi (气) or the vital energy, Being is the condensation of Qi, emptiness is the origin of Being, and the destination of diffused Qi. Therefore, Being and Nothing are not contradictory, but two patterns of Qi. The difference in Chinese and Western philosophy certainly causes the different views of art, an obvious example is the difference between the oil painting, which leaves no blank space, and traditional Chinese painting, which attaches great importance to blank places. Blankness and fillings are mutually symbiotic; though the lines break off, the ideas connect. This mode of thinking, applied in poetry writing, gives a clear and empty Yijing. WANG Wei's poems combine the ideal and artistic beauty of Yijing, and give subtle but profound implications. Following is his poem "The Vale of Singing Birds" (700AD):

In leisure time, the petals of osmanthus flowers fall;
The nocturnal quiet empties the mountains in spring.
Birds, startled by the rising moon,
Burst into song now and then in the spring vale. ${ }^{9}$

The chirping birds and bright moon are audio-visual elements. The poet did not employ something silent and still to delineate the serene and empty mountain, but recorded voices and colors. By contrast, the mountain is more serene and empty. If it is described as deadly quiet, the poetic aroma will be lost. Now look at another poem "Lily Magnolias Fence” (700AD):

The setting sun glowing on the autumn mountain,
Flying birds follow their companions.
The gaudy green color is flashing,
The shapeless evening mist is floating. ${ }^{10}$

The brilliantly charming scenery is not steady; it will soon vanish and turn the rich substance into emptiness in a blink. Emptiness and substance are the same, so seeing things is seeing the mind, forget things when one sees the mind. The SONG Dynasty poetry critic YAN Yu (严羽, about 1192 AD-1241 AD) adopted the aesthetics of Zen Buddhism to build up his poetics, "music from the heaven, color of the picture, moon in the water, image in the mirror"11. The crystal clean Yijing of the above two poems is a dreamland, in which all vexations and worries are cleansed away, only beauty left. HU Ying-lin's (1551 AD-1602 AD) annotation to WANG Wei's poetry goes like this, "smooth but not rude, profound but not repressed, gorgeous but not apathetic, almost emptied in both substance and form, it is extremely elegant and refined"12.

The other difference lies in clarity and vagueness. English poetic tradition mostly tries to clarify, while Chinese

\footnotetext{
9 “人闲桂花落, 夜静春山空, 月出惊山鸟, 时鸣春涧中” (WANG, 1997, p. 637).

10 “秋山敛馀照，飞鸟逐前侣。彩翠时分明，夕岗无处所” (WANG, 1997, p. 418).

11 “空中之音，相中之色，水中之月，镜中之像” (HE, 1981, p. 688).

12 “和平而不暴气, 深厚而不伤格, 浓丽而不乏情, 几于色相俱空, 风雅备极” (HU, 1979, p. 83).
} 
philosophy accepts the concept of vagueness, it does not bother to vainly explore the Truth, because the "Tao (the Way) is elusive” (道之为物, 惟恍惟惚, 《老子. 二十一章》, n.d.). Chinese view of art is indeed a kind of intuitionism, like that described in Sikong Tu’s (837 AD-908 AD) “The Floating and Serene Style” (900 AD):

In deep isolation, ready to take off, one is proud and aloof. Like the crane from Hou Mountain, or clouds at the peak of Hua Mountain. A hermit with harmony inside, Has a mild and smiling face. A flying weed tumbling on the wind, He floats across boundless space. Hard to grasp this style, But you can almost hear it. Those who understand, wait. If you desire it, it will retreat. ${ }^{13}$

This is also due to linguistic difference; language is considered as a tool for English poets. Chinese culture degrades the use of any tools, “the Tao is superior, while the tool is inferior” (形而上者谓之道 , 形而下者谓 之器《周易正义·系辞上》, n.d.). Language as a tool of literature is also degraded. Chinese culture knows the implicitness and unspeakability of language, “the Tao that can be told, is not the eternal Tao” (道可道 , 非常 道《老子. 一章》, n.d.), “once one has got the meaning, one should forget the language” (得意而忘言《庄 子. 杂篇. 外物》, n.d.), “the heaven and earth possess the supreme beauty but only speechless” (天地有大 美而不言《庄子. 知北游》, n.d.), LIU Xie (刘妿思, 465 AD-520 AD) wrote in his authoritative Wen Xin Diao Long (《文心雕龙》, $502 \mathrm{AD})$ :

That subtle implication behind the mind, that ulterior suggestion beyond the spoken: these things cannot be pursued by language, or be stated in literature. It takes an appreciation of ultimate realm to explain the exquisite, an understanding of absolute change to perceive the artistry. Yi Yin could not tell you about the cooking in the cauldron, no more could wheelwright Bian communicate to you the wielding of the axe, such being the mystery of these mechanisms. ${ }^{14}$

Chinese poetic criticism serves as an initiator or indicator, it enlightens the reader to get the quintessence and forget the tool or channel. The metaphysical quality of literature like Yijing does not count for much in English literary criticisms.

The formation of English language makes English poetry hard to achieve Yijing as that in Chinese poetry. With the development of cultural communication, modern American poetry was inspired by classical Chinese poetry. English poets after the Second World War struggled to shake off the language limitations. Pound (1885 AD-1972 AD) used the juxtaposition of images and removed the unnecessary words that were considered as redundancy. The Beat Generation poet Gary Snyder (1930- ) assimilated more artistry from Chinese poetry, he practiced Zen Buddhism and learned TANG Dynasty monk Han Shan’s (寒山, about 691 AD-793 AD) style, his poetry achieved deep and broad Yijing.

\section{Conclusions}

In the past, Chinese scholars in comparative literature mostly employed western literary theory to interpret Chinese literary texts. This paper aims at the counter-interpretation, that is using Chinese literary theory of Yijing to interpret Wordsworth's nature poetry. From this perspective, the artistic value of Wordsworth's nature poetry emerged more clearly than it is in the western literary tradition. Wordsworth’s stylistic handling of nature

13 “落落欲往, 矫矫不群。缑山之鹤, 华顶之云。高人画中, 令色氮氲。御风蓬叶, 泛彼无垠。如不可执, 如将有闻。 识者已领，期之愈分” (HE, 1981, p. 44).

14 “至于思表纤旨, 文外曲致, 言所不追, 笔固知止。至精而后阐其妙, 至变而后通其数, 伊挚不能言鼎, 轮扁不能语 斤 , 其微矣乎 ! ” (LIU, 1958, p. 495). 
poetry is innovative in the history of English poetry. His aesthetical perception transcended his own age, all these can be better appreciated by Chinese aesthetics. Though they share similarities in poetics Yijing, one should always be cautious about the essential differences. LIU Yu-xi (772 AD-842 AD) commented: "Poetry is a difficult one among literary genres, once the meaning becomes evident; the language dies. This esoteric feature makes it hard to be proficiently mastered. Yijing goes beyond the imagery; its exquisiteness resists any imitation” ${ }^{\prime 15}$. Chinese poetry follows the lead of Yijing, and freely pursues the intuitive beauty that does not cling to objects. Chinese philosophy and art know the limitations of objects and tools. Chinese poets give up the pursuit for a clear description of Yijing, interestingly; this ingenious concession yields the perfection of poetry and the efflorescence of poetics.

\section{References}

Beijing Daxue Zhexuexi (Departement of Philosophy, Peking University) (Ed.). (1981). Zhongguo Meixueshi Ziliao Xuanbian (Annotatins of Chinese aesthetics). Beijing: Zhonghua Shuju.

GUO, S. Y. (Ed.). (2001). Zhongguo Lidai Wenlun Xuan (Selections of traditional Chinese literaray criticisms). Shanghai: Shanghai Guji Publishing House.

HE, W. H. (Ed.). (1981). Lidai Shiahua (Classcial Chinese poetics). Beijing: Zhonghua Shuju.

HU, Y. L. (1979). Shishu (Collection of Poetry). Shanghai: Shanghai Guji Publishing House.

Keats, J. (1970). The complete poems. Harlow, UK: Longman.

LIU, X. (1958). Wen Xin Diao Long (Literary mind and carving of dragon). Beijing: People's Literature Publishing House.

LU, J. (2002). Wenfu (Commentations on literature). Beijing: People’s Literature Publishing House.

Sidney, P. (2002). An apology for poetry. Manchester UK: Manchester University Press.

WANG, W. (1997). Wang Wei Ji Jiaozhu (Annotation to Wang Wei's poetry). Beijing: Zhonghua Shuju.

Wordsworth, W. (2001). Selected poetry of William Wordsworth. New York: The Modern Library.

ZONG, B. H. (2005). Tianguang Yunying (Sky light and shadow of clouds). Beijing: Beijing University Press.

15 “诗者其文章之蕴邪? 义浔而言丧, 故微而难能, 境生于象外, 故精而寡和” (GUO, 2001, p. 90). 